\title{
HERCEG STJEPAN VUKČIĆ KOSAČA I POLIMLJE
}

\author{
Marijan PREMOVIĆ \\ Univerzitet Crne Gore \\ Filozofski fakultet \\ Studijski program za istoriju \\ Danila Bojovića b.b. \\ 81400 Nikšić, Crna Gora \\ E-pošta: premovicmarijan@yahoo.com
}

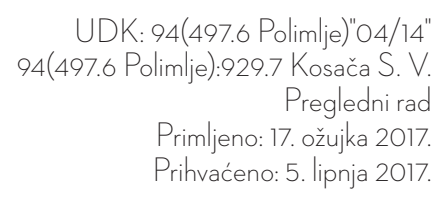

UDK: 94(497.6 Polimlje)"04/14"

Pregledni rad

Prihvaćeno: 5. lipnja 2017.

Sažetak

Rad pruža pregled povijesnih činjenica o Polimlju (Srednjem i Donjem) u doba hercega Stjepana Vukčića Kosače. Pojam Polimlje odgovara prostoru srednjovjekovnih župa: Crne Stene (teritorija općine Prijepolje, Srbija) i Dabra (obuhvaća općinu Priboj u Srbiji i Rudo u Bosni i Hercegovini). Na osnovi arhivskih dokumenata, diplomatičke građe, osmanskih popisa iz 1468./1469. i 1475./1477. godine, terenskih istraživanja i relevantne povijesne literature prikazali smo političke prilike, granicu između Kosača i Despotovine u Polimlju, privredni razvoj, gradove i tvrđave.

Ključne riječi: Stjepan Vukčić Kosača; kasni srednji vijek; Polimlje; političke prilike; granica; trgovinski odnosi. 
Naziv "Polimlje" prvi je put zabilježen 1444. godine u povelji kralja Alfonsa V. prilikom popisa gradova hercega Stjepana Kosače (Creseuaz Opolimi; grad Kreševac - Hrsovac). Drugi pisani podatak koji se odnosi na Polimlje zabilježen je pet godina kasnije u jednom dubrovačkom dokumentu. U seriji Lamenta de foris zabilježeno je, da je Dmitar Vukošić que stat sub Seuerino in Polimie, hamo domini chercech Stiepani, opljačkao i ubio jednog Dubrovčanina (30. I. 1449.). U ovim srednjovjekovnim pisanim izvorima Polimlje se izgleda odnosilo samo na kraj oko Donjeg Polimlja, ispod Dabra. ${ }^{1}$ U sumarnom popisu sandžaka Bosna iz 1468./1469. godine za seoska naselja Marsova, Gorna Obrveno i Gorna Kostil navodi se da pripadaju nahiji Polimlju. Smatra se da se središte nahije Polimlje nalazilo na prostoru današnjeg Rudog. ${ }^{2} \mathrm{U}$ poimeničnom popisu Hercegovine iz 1475./1477. godine zabilježeno je da nahije Mileševa, Ljuboviđa i Kukanj pripadaju Polimlju. Tako se od druge polovice XV. stoljeća ime Polimlje proširilo na čitavo Donje i Srednje Polimlje (pribojski, prijepoljski i bjelopoljski kraj). ${ }^{3}$

Na prostoru Srednjega i Donjega Polimlja u povijesnim izvorima i literaturi spominju se kao župe pet manjih ili većih cjelina: Lim, Ljuboviđa, Zvijezd, Crna Stena i Dabar. ${ }^{4}$

Župe su stare slovenske administrativne jedinice, koje su se formirale uz rijeke, uz koje se nalazi zemljište pogodnije za obrađivanje. U Etimologijskom rječniku hrvatskoga ili srpskoga jezika Petra Skoka za-

1 Minailo Dinić, Srpske zemlje u srednjem veku, Srpska književna zadruga, Beograd, 1978., str. 241-242, 250; DeSANKA KovaČEvić-KoJIć, Gradska naselja srednjovjekovne bosanske države, IP "Veselin Masleša", Sarajevo, 1978., str. 111, bilj. 145. O okolnosti nastanka isprave iz 1444. godine vidjeti u daljem radu.

2 Ahmed S. Aličić, Sumarni popis sandžaka Bosna iz 1468/69. godine, Islamski kulturni centar Mostar, Mostar, 2008., str. 209, 221, bilj. 3061.

3 Ahmed S. Aličić, Poimenični popis sandžaka vilajeta Hercegovina, Orijentalni institut u Sarajevu, Sarajevo, 1985., str. 31, 40, 50.

4 Radoslav Mijatović, "Srednjovekovne župe duž Lima", u: Simpozijum Seoski dani Sretena Vukosavljevića, VII., Prijepolje, 1979., str. 209-223; GordanA Tomović, "Župa Crna Stena", u: Simpozijum Seoski dani Sretena Vukosavljevića, XIV., Prijepolje, 1992., str. 161-171; SinišA Mišıć, "Teritorijalno-upravna organizacija Polimlja (XII-XIV vek)", u: Kralj Vladislav i Srbija XIII veka, Beograd, 2003., str. 73-88; Gordana Tomović, "Župa Ljuboviđa", u: Kralj Vladislav i Srbija XIII veka, Beograd, 2003., str. 47-62; Gordana Tomović, "Dabar", u: Mileševski zapisi, 6, Prijepolje, 2005., str. 35-44; Marijan Premović, Župa Budimlja u srednjem vijeku, Državni arhiv, Cetinje, 2012. 
pravo je ono prvobitno i najstarije značenje župe koje se sačuvalo do danas: "kraj izložen suncu, prisoje, umina, gdje ne pada snijeg ili, ako padne, odmah okopni". ${ }^{5}$ Osim brojnih kotlinskih zaklonjenih oblasti koje se u narodu nazivaju župama, neke su do dana današnjega sačuvale svoj naziv. ${ }^{6}$ U Polimlju župa je najmanja upravna i teritorijalna jedinica. Kao opći pojam predstavlja pitomu oblast s obradivom zemljom i blagim pogodnim klimatskim uvjetima. ${ }^{7}$ Za oblikovanje župa u srednjem vijeku bilo je važno postojanje seoskih, ruralnih kršćanskih zajednica, budući da su one sadržavale sve elemente potrebne za gospodarski i društveni život. ${ }^{8}$

Prvi poznatiji član obitelji Kosača, Vlatko Vuković, imao je u svome posjedu Donje Polimlje i dio Srednjeg Polimlja s manastirom Mileševom i Prijepoljem. Za vjerno izvršavanje službe kralj Tvrtko ga je nagradio teritorijalnim posjedima bosanske države na jugoistočnim granicama, a to su bili nekadašnji prostori Nikole Altomanovića. ${ }^{9}$ Njegove posjede naslijedio je njegov sinovac Sandalj Hranić 1392. godine. Nasljeđujući dio Polimlja od svoga strica, on je preko gra-

5 Etimologijski rječnik hrvatskoga ili srpskoga jezika, knj. 3, Poni-Žl, Mirко DEanović - Ljudevit Jonke (ur.), za tisak priredio Valentin Putanec, Jugoslavenska akademija znanosti i umjetnosti, Zagreb, 1988., str. 687-688.

6 Današnji geografski nazivi pojedinih oblasti kao što su: Nikšićka Župa, Velika Župa kod Prijepolja, Aleksandrovačka Župa, sačuvali su osnovno značenje riječi na balkanskom prostoru, time potvrđujući da se nisu mijenjala dva osnovna svojstva župe: poseban geografski položaj i klimatski uvjeti. M. Premović, Župa Budimlja u srednjem vijeku, str. 23, bilj. 38.

7 Vidjeti opširnije: Stojan Novaković, Selo, Srpska književna zadruga, Beograd, 1965., str. 28-40; KonstAntin JiReČEK, Istorija Srba, II., Slovo ljubve, Beograd, 1978., str. 4-5; Miloš Blagojević, "Grad i župa - međe gradskog društva", u: Jovanka Kalić - Milosav Čolović (ur.), Socijalna struktura srpskih gradskih naselja (XII-XVIII vek), Beograd - Smederevo, 1992., str. 6784; Gordana Tomović, "Srpska srednjovekovna župa u delima Stojana Novakovića", u: Vladimir StojančEvić (ur.), Stojan Novaković - ličnost i delo. Naučni skup povodom 150-godišnjice rođenja (1842-1992), Beograd, 1995., str. 293-298; Siniša Mıšić, "Zemlja u državi Nemanjića", u: Godišnjak za društvenu istoriju, 2-3, Beograd, 1997., str. 133-134; Gordana Tomović, "Župa", u: Leksikon srpskog srednjeg veka, Sima Ćirković - RAde MinaljČić (prir.), Beograd, 1997., str. 195-197; M. Premović, Župa Budimlja u srednjem vijeku, str. 21-23.

8 Franjo Smiljanić, "Prilog proučavanju županijskog sustava sklavinije Hrvatske", u: Branimir Donat (ur.), Etnogeneza Hrvata, Zagreb, 1995., str. 187.

9 Esad Kurtović, Veliki vojvoda bosanski Sandalj Hranić Kosača, Institut za istoriju, Sarajevo, 2009., str. 37-42. 
ničnoga posjeda, zapravo preko posjeda Vuka Brankovića, došao u dodir s Osmanlijama i vjerojatno je aktivno sudjelovao u pružanju otpora Osmanlijama. U ožujku 1435. ugasio se život vojvode Sandalja. ${ }^{10}$ Sahranjen je u svojoj zadužbini u crkvi Svetoga Stefana na Šćepan Polju. ${ }^{11}$

Naslijedio ga je sinovac Stjepan Vukčić, sin kneza Vukca Hranića. ${ }^{12}$ Primivši u nasljeđe prostrane zemlje i složena savezništva, Stjepan Vukčić naslijedio je i protivnike koji su se željeli okoristiti Sandaljevom smrću i ubrzo je bio izložen napadima kralja Žigmunda i Radoslava Pavlovića. Ovaj put Stjepan je pozvao Osmanlije i uz njihovu se pomoć uspio obraniti. Na početku ovoga ratnog sukoba veće je uspjehe imao Radoslav. Grad Jeleč u Gornjem Podrinju došao je u posjed Pavlovića. Poslije ovih polaznih uspjeha vojvoda Stjepan je početkom 1438. godine povratio grad Jeleč (Radencho Obiacich loqual fo de Bossina de sotto Jellez et fo homo de Radossavo Paulovich. Et adesso quello paixe sie de Stipan Vocçich, 4. V. 1438.) i oduzeo Trebinje Pavlovićima, koje je kasnije ipak morao vratiti. Do lipnja 1439. sklopljen je mir s Pavlovićima, i tada je dogovorena bračna veza Radoslava sa Stjepanovom sestrom Teodorom. ${ }^{13}$ Ovu zauzetost Stjepanovu u sukobu s Pavlovićima iskoristio je despot Đurađ Branković, pa se u ugovoru koji je sklopljen 26. srpnja 1435. između vlaha ponosnika i dubrovačkih trgovaca navodi da je njihovo odredište usque Pripoglie districtum Sclavonie. Prijepolje je, izgleda, samo na kratko bilo u sastavu Despotovine. ${ }^{14}$ Nekoliko mjeseci kasnije (6. XI. 1435.) ponosnici u Dubrovniku nisu smjeli preuzeti rizik za prijenos robe do Prijepolja u slučaju napada osmanske vojske ili vojvode Stjepana. ${ }^{15}$

10 Sima Ćirković, Herceg Stefan Vučić-Kosača i njegovo doba, Naučno delo, Beograd, 1964., str. 10; E. KurTović, Veliki Vojvoda Bosanski Sandalj Hranić Kosača, str. 329-331.

11 Marko Popović, "Soko Grad nad Šćepan Poljem - Zamak sa zadužbinama Kosača", u: Gordana Tomović (ur.), Šćepan Polje i njegove svetinje kroz vjekove, Sveviđe, časopis eparhije Budimljansko-nikšićke - Manastir Zagrade, Berane, 2010., str. 21-23.

12 E. Kurtović, Veliki vojvoda bosanski Sandalj Hranić Kosača, str. 59.

13 M. Dinić, Srpske zemlje u srednjem veku, str. 194; S. Ćır Ković, Herceg Stefan Vučić-Kosača i njegovo doba, str. 8-39.

14 Ruža Ćuk, "Kosače i Polmlje", u: Radoslav Bratić (prir.), Kosače-osnivači Hercegovine, Bileća - Gacko - Beograd, 2002., str. 383.

15 Dobravaç Milichevich et Dobravaç Crebeglianovich... se obligaverunt... crastino die de Ragusio sine dilatione portare in Priepogle ad viam de Jesera... salvo 
Do sredine 1439. Stjepan je uspio očuvati nasljeđe svoga strica, a protivnici Kosača dobili su odgovor da je riječ o odlučnom i energičnom nasljedniku vojvode Sandalja.

Velika promjena nastala je 1439. godine na granici prema Kosačama u Polimlju, tada su Srbiju prvi put osvojili Osmanlije. Osmanska granica došla je tada u neposrednu blizinu Prijepolja. Postoji mišljenje da je osmanska posada ušla u grad Mileševac 1439. godine. ${ }^{16}$

Ove promjene praćene prisustvom Osmanlija utjecat će na nesigurnost dubrovačkih trgovaca na putevima prema Polimlju. Nemamo podatke o Stjepanovim posjedima u Polimlju od 1439. do 1444. godine u povijesnim izvorima. ${ }^{17}$

Poslije smrti kralja Tvrtka II. ujesen 1443. godine započeo je period velikoga neprijateljstva između novoga kralja Stjepana Tomaša i vojvode Stjepana Vukčića, zato što je bio protiv njegova dolaska na prijestolje i podržavao Radivoja da postane bosanski kralj. Kosača se još bliže povezao sa Osmanlijama. Kralj Tomaš je našao za saveznika Ivaniša Pavlovića u Bosni, a od drugih država Venecija mu je bila najprirodnija jer je bila u ratu s Kosačama. Mlečani su istisnuli vojvodu iz Donje Zete, a kralju Tomašu i vojvodi Ivanišu prišli su vojvoda Sladoje Semković i Radivojevići. Početkom siječnja 1444. ovaj savez postigao je velike uspjehe protiv vojvode Stefana. Saveznici su uspjeli da ga potisnu u dolinu Neretve, a u veljači 1444. Drijeva je bila u njihovim rukama. ${ }^{18} \mathrm{U}$ takvoj situaciji Stjepan Vukčić je bio prisiljen da potraži saveznika i zaštitnika na drugoj strani. On je zatražio od aragonsko-napuljskoga kralja Alfonsa V. da se zauzme za njega kod rimskog cara i kršćanskih vladara i ponudio mu da postane njegov vazal. Najvažniji dokument koji je nastao u ovim pregovorima jest povelja izdata u Napulju 19. veljače 1444., kojom Alfons V. potvrđuje sve pobrojane posjede vojvode Stjepana. Povelja kralja Alfonsa

ab exercitu Thurcorum et voivode Stefani. DržAvni ArHiv u Dubrovniku (dalje: DADU), Diversa Notariae, sv. 20, f. 67, 6. XI. 1435.

16 Hazım ŠA BAnović, Bosanski pašaluk: postanak $i$ upravna podjela, Naučno društvo NR Bosne i Hercegovine, Sarajevo, 1959., str. 28.

17 Sima Ćirković, "Prijepolje u srednjem veku", u: Simpozijum Seoski dani Sretena Vukosavljevića, III., Prijepolje, 1976., str. 222.

18 S. Ćirković, Herceg Stefan Vučić-Kosača i njegovo doba, str. 71-75; MithaD Spahić, "Odnosi hercega Stjepana Vukčića Kosače i kralja Stjepana Tomaša", u: Munib Maglajlić (ur.), Naučni skup herceg Stjepan Vukčić Kosača i njegovo doba, Mostar, 2005., str. 78. 
otkriva šta su obje strane nudile jedna drugoj i tražile. "Predavajući" se kralju Stjepan je nudio da izdržava 1000 napuljskih konjanika (napuljska strana je izračunala da je to 32.004 dukata godišnje), ali je zauzvrat tražio da se Alfons zauzme kod rimsko-njemačkoga cara, Venecije, bosanskoga kralja i vojvode Ivaniša Pavlovića da mu se vrate oduzeti posjedi. Kralj ne samo da na to nije pristao nego je pristao da će uložiti takav trud kao da je u pitanju njegov teritorij. Budući da su pregovori završeni uspješno, ugovor između dvije strane je zaključen do 15 . veljače $1444 .{ }^{19}$

Drugom poveljom izdanom 1448. godine to isto čini i Fridrih III., a 1. lipnja 1454. Alfons V. izdaje novu povelju, sa sličnim sadržajem kao povelja iz 1444. godine. Ove povelje prvorazredni su izvor podataka o posjedima Stjepana Vukčića. U njima su označena utvrđena mjesta (castra) i u većini slučajeva daje se ime župe. Veliki broj utvrđenih gradova navedenih u poveljama iz 1444., 1448. i 1454. godine nalazi se u Polimlju (Srednjem i Donjem). Utvrđeni gradovi s vojnim posadama štitili su važne puteve i prolaze, a prema rasporedu gradova navedenih u poveljama može se sagledati organizacija obrambenoga sustava. Većina njih ima veliki strategijski značaj: kontrolira dolinu Lima ili brane prilaze kroz kanjone manjih rječica. Na ovome prostoru popisano je šest utvrda: Mileševac, Kovin, Oštrik, Klek, Severin i Hrsovac. $^{20}$

Grad Mileševac bio je utvrda manastira Mileševe, smješten na vrhu litice, na ulazu u klisuru rijeke Mileševske, udaljen je dva km jugoistočno od manastira Mileševe, sedam km istočno od Prijepolja, na mjestu

19 Ludwig von Thallóczy, Studien zur Geschichte Bosniens und Serbiens im Mittelalter, Duncker \& Humblot, München - Leipzig, 1914., str. 359-363; M. Dinić, Srpske zemlje u srednjem veku, str. 178-251; S. ĆIRKović, Herceg Stefan Vučić-Kosača i njegovo doba, str. 75-77; MARKo Vego, Iz historije srednjovjekovne Bosne i Hercegovine, Svjetlost, Sarajevo, 1980., str. 452-486; MomČIlo Spremić, Prekinut uspon: srpske zemlje u poznom srednjem veku, Zavod za udžbenike i nastavna sredstva, Beograd, 2005., str. 356.

20 M. Dinić, Srpske zemlje u srednjem veku, str. 178-251; S. Ćırкоvić, Herceg Stefan Vučić-Kosača i njegovo doba, str. 75-77; Dušica Minić, "Nekoliko srednjovekovnih gradova u Srednjem Polimlju", u: Seoski dani Sretena Vukosavljevića, IV., Prijepolje, 1976., str. 101-110; MARko Vego, Iz historije srednjovjekovne Bosne i Hercegovine, str. 452-486 (s faksimilima povelje iz 1444. i 1448.); Dušan Spasić, "Srednjovekovni utvrđeni gradovi srednjeg Polimlja", u: Mileševski zapisi, 2, Prijepolje, 1997., str. 35-68; R. Ćuk, "Kosače i Polmlje", str. 383; Jusuf Mulić, Hercegovina, Prvi dio: Feudalna oblast srednjovjekovne bosanske države, Muzej Hercegovine, Mostar, 2004., str. 69-72. 
današnjega naselja Hisadžrik. ${ }^{21}$ Grad se prvi put spominje u povelji Alfonsa V. iz 1444. kao Mileseuischi. On se spominje u povelji kralja Fridriha III. 1448. Mileschetsky, a u drugoj Alfonsovoj povelji iz 1454. kao Mileseuschi. ${ }^{22}$ Osmanlije su Mileševac osvojili 1465. godine. ${ }^{23}$

Srednjovjekovna tvrđava Kovin (narod je naziva i Jerinin grad) nalazi se na oko osam kilometara sjeverno od Prijepolja, na lijevoj obali Lima, u blizini sela Džurova, na vrhu kamenitog uzvišenja. Kao tvrđava Stjepana Vukčića Kosače spominje se u poveljama Fridriha III. iz 1448. (castrum Conin) i Alfonsa V. iz 1454. godine (civitate Chovino). ${ }^{24}$ Tvrđavu Kovin spominje turski putopisac Evlija Čelebija. Prema njegovu kazivanju grad je podignut za vrijeme srpskih kraljeva, a osvojen je za vrijeme Kosovske bitke. Međutim, ne postoje pouzdani podatci o tome da je Kovin sagrađen prije XV. stoljeća. ${ }^{25}$

Grad Oštrik se prvi put spominje u povelji kralja Fridriha III. 1448. godine, iza Mileševca, Kovina i Severina. U drugoj povelji (1454.) spominje se između Mileševca i Kovina. Najnovija arheološka istraživanja locirala su ostatke tvrđave na brdu Oštrik u Zlatarskim Čelicama. ${ }^{26}$

Tvrđava Klek se prvi put spominje u povelji iz 1444. godine (Chechnauchoy castello con lo contato). Nalazila se na granici prema Despotovini. Prema našem mišljenju Klek se nalazio na lokalitetu Gradini u Rutošima, jer je sjevernije selo Radohinja bilo u posjedu kneza Lazara. Tvrđava Klek u selu Rutoši nalazi se na oštrom zavoju rijeke Uvac, pa je prirodno okružena s tri strane rijekom, tako da je prilaz

21 D. Spasıć, nav. dj., str. 51; "Mileševac", u: Leksikon gradova i trgova srednjovekovnih srpskih zemalja - prema pisanim izvorima, Beograd, 2010., str. 180.

22 M. Dinić, Srpske zemlje u srednjem veku, str. 198-199.

23 Hatidža ČAR-Drnda, "Prilog proučavanju prošlosti grada Mileševca", u: Seoski dani Sretena Vukosavljevića, XI., Prijepolje, 1985., str. 113.

24 D. Minić, "Nekoliko srednjovekovnih gradova u Srednjem Polimlju", str. 104; M. Dinić, Srpske zemlje u srednjem veku, str. 199-200; D. Spasić, nav. dj., str. 49-51; "Kovin", u: Leksikon gradova i trgova srednjovekovnih srpskih zemalja - prema pisanim izvorima, str. 130-131.

25 Evlija Čelebija, Putopis, odlomci o jugoslovenskim zemljama, preveo, uvod i komentar napisao Hazım Šabanović, Svjetlost, Sarajevo, 1967., str. 388.

26 M. Dinić, Srpske zemlje u srednjem veku, str. 251; M. VEgo, Iz historije srednjovjekovne Bosne i Hercegovine, str. 472, 484; RAdovan BunARdžIć - MArina Bunardžić - Savo Derikonjić, Topografija Polimlja-arheologija, sv. 1, Republički zavod za zaštitu spomenika kulture, Beograd, 2008., str. 48-60. 
jedino bio moguć s jugozapadne strane. Kao hercegov posjed navodi se u poveljama Fridriha III. (1448.) i Alfonsa V. (1454.). ${ }^{27}$

Na prostoru između Priboja i Rudog nalazi se srednjovjekovni utvrdeni grad Severin. Ostatci utvrde danas se nalaze na vrhu brda Međustene, oko dva km jugoistočno od današnjega Sjeverina. ${ }^{28}$ Prvi pisani podatak o gradu potječe iz povelje Alfonsa V. 1444. godine (Serauansche, castello con contato). Severin se ubraja u manje poznate i veoma rijetko posjećivane karavanske stanice u Polimlju. Uz utvrđenje razvilo se podgrađe, u jednoj dubrovačkoj parnici od 30. siječnja 1449., navodi se sub Seuerino in Polimie. On se spominje u povelji Fridriha III. 1448. (castrum Serverin), kao i povelji Alfonsa V. iz 1454. godine (civitate Severino cum castris et pertinentiis). ${ }^{29}$ Severin je u poimeničnom popisu iz 1475./1477. godine popisan kao selo, čiji su prihodi ulazili u sastav timara Arslana i Arnauta Karađoza, posadnika tvrđave Mileševac. ${ }^{30}$

Grad Hrsovac se spominje u sve tri povelje Stjepana Vukčića Kosače (1444., 1448., 1454.), kao njegov posjed..$^{31}$ Ovaj grad nalazio se ispod Severina, a na tom prostoru postoji lokalitet Gradina na koti 1191, koja nije arheološki istražena. U neposrednoj blizini lokaliteta nalazi se toponim Hrašće. Očito je utvrda Hrsovac imala vojno stratešku namjenu u nizu utvrda Kosača na granici prema srpskoj Despotovini. ${ }^{32}$

27 M. Dinić, Srpske zemlje u srednjem veku, str. 198; Vukoman ŠAlipurović, "Neka pitanja granice Bosne i Hercegovine i Despotovine u XIV i XV veku i mesta i položaja nekih srednjovekovnih gradova u Srednjem Polimlju", u: Seoski dani Sretena Vukosavljevića, VII., Prijepolje, 1979., str. 197-198; VukADin Obrenija - Dušica Minić, "Grad Klek u selu Rutoši", u: Raška baština, 2, Kraljevo, 1980., str. 308-309; "Klek", u: Leksikon gradova i trgova srednjovekovnih srpskih zemalja - prema pisanim izvorima, str. 127; SinišA Mišıć, Studije o srednjovekovnom Polimlju, Filozofski fakultet, Niš, 2012., str. 73.

28 M. Nikolić, "Dva srednjovekovna grada u jugozapadnoj Srbiji", u: Užički zbornik, 4, Titovo Užice, 1975., str. 35-39; D. Spasić, nav. dj., str. 42-43; "Severin", u: Leksikon gradova i trgova srednjovekovnih srpskih zemalja - prema pisanim izvorima, str. 253.

29 M. Dinić, Zemlje hercega Svetoga Save, str. 241-242.

30 A. S. Aličić, Poimenični popis sandžaka vilajeta Hercegovina, str. 593; EMA Miljković, "Osmansko osvajanje Hercegovih poseda u Polimlju", u: Mileševski zapisi, 9, Prijepolje, 2012., str. 111.

31 M. Dinić, Srpske zemlje u srednjem veku, str. 250.

32 D. Spasıć, nav. dj., str. 64, bilj. 121; "Hrsovac", u: Leksikon gradova i trgova srednjovekovnih srpskih zemalja - prema pisanim izvorima, str. 314. 
Promjene mijenjanja granice u Donjem i Srednjem Polimlju mogu se pratiti kroz dubrovačke izvore, koji nas o tome na nekoliko mjesta izričito obavještavaju. ${ }^{33}$ Dubrovčani su brižljivo bilježili smjene vlasti i pomicanje granice, kojima je izgleda najviše bilo izloženo Donje Polimlje. Kao pogranična oblast između Kosača, Pavlovića i Srbije, ovo područje postaje predmet njihovih pretenzija. Njihova sukobljavanja naročito su izražena krajem XIV. i u prvim desetljećima XV. stoljeća. ${ }^{34}$

33 Krajem XIV. i početkom XV. stoljeća granica u Polimlju između Kosača i Despotovine bila je dinamična i često se mijenjala. Na pomicanje granice utjecali su razni politički čimbenici: česte promjene na bosanskom prijestolju, ratovi Bosne s Dubrovnikom i Ugarskom, sukobi Sandalja i antagonizmi s ostalim oblasnim gospodarima, njegova zauzetost teritorijalnim aspiracijama i osvajanjima na jugu i na jugoistoku (Sandalj je stekao i posjed porodice Sanković i tako izašao na rijeku Neretvu), prodor Turaka i njihovo uplitanje u unutrašnje sukobe.

34 U dokumentima se naglašava da područje oko manastira Svetog Nikole 1395. i 1397. godine pripada Bosni (contrata S. Nicolai de Bagna partiuim Bossine, 1395; contrata S. Nicolai de Bagna partiuim Bossine, 27. XI. 1397.); KonstAnTIN JiREČEK, "Hrišćanski element u topografskoj nomenklaturi balkanskih zemalja", u: Minailo Dinić (ur.), Zbornik Konstantina Jirečeka, I., Naučno delo, Beograd, 1959., str. 487; V. ŠAlipurović, nav. dj., str. 196; Mirjana ŠAкотA, Riznica manastira Banje kod Priboja, Republički zavod za zaštitu spomenika kulture, Beograd, 1981., str. 17; U srednjem vijeku postojala su dva Dabra: Dabar u Donjem Polimlju i Dabar u Humskoj zemlji. Dubrovački izvori izričito su bilježili kada je u pitanju humski Dabar u Bosni (de Dabar Regni Bossina; de Dabar Regni Bosna). DADU, Diversa Cancellariae, sv. XXXIII., f. 119, 12. VIII. 1398.; DADU, Div. Canc., sv. XXXV., f. 57', 2. IV. 1404.; U jednom ugovoru od 30. IV. 1395. za Dabar se kaže de Dabar, partium Sclavonie. Tri godine kasnije, u srpnju 1398. spominje se Veselko pokojnog Milše Čekanića de Xadbra partium Sclavonie. DADU, Div. Canc., sv. XXXI., f. 157’, 30. IV. 1395.; DADU, Div. Canc., sv. XXXIII., f. 119, 12. VIII. 1398. Pod terminom Sclavonia u Dubrovačkim arhivskim knjigama isključivo se označava Srbija. M. Dinić, Srpske zemlje u srednjem veku, str. 33-36; Usp. U odlukama Malog vijeća (Acta Consilii Minoris) od 1415. do sredine 1460. koje se odnose na Srbiju vidjeti spomene termina Sclavonia. Andrija Veselinović, Dubrovačko Malo veće o Srbiji (1415-1460), Istorijski institut SANU - Istorijski arhiv Kraljevo - Istorijski arhiv Čačak, Beograd, 1997.; U jednoj bilješci iz Dubrovačkog arhiva saznajemo da je Banja 1405. godine bila u vlasti kneza Pavla Radinovića. Sima Ćır ković, "Pavlovića zemlja (Contrata de Paulovich)", u: Milan Vasić (ur.), Zemlja Pavlovića-srednji vijek i period turske vladavine, Akademija nauka i umjetnosti Republike Srpske, Banja Luka - Srpsko Sarajevo, 2003., str. 41; Tijekom 1405. godine i Bukovica je ušla u sastav teritorija kneza Pavla. O tome nam govori sljedeći podatak. Tijekom rujna 1405. vlasi ponosnici trebali su prenijeti 52 tovara 
Granica između Despotovine i oblasti Kosača išla je od ušća Uvca Limom, i negdje između Svetog Nikole i grada Kovina na lijevoj obali Lima, kod sela Džurova, prelazila na desnu obalu. Utvrđeni grad Severin nalazio se u rukama Kosača. Lijeva strana Lima bila je u njihovim rukama. ${ }^{35} \mathrm{Na}$ desnoj strani Lima, prema njegovu ušću, graničili su posjedi Kosača i Pavlovića, pod vlašću Pavlovića bili su grad Brodar i planina Bujak. Njima je pripadala i Ustikolina, Međeđa, Višegrad i Dobrun. ${ }^{36}$ Današnja planina Vrada iznad Rudog nalazila se na tromeđi Despotovine, Pavlovića i oblasti Kosača. ${ }^{37}$ Južni obronci planine Jahorine bili su međa Pavlovića i Kosača, a negdje ispod Goražda granica je presijecala rijeku Drinu. ${ }^{38}$ Ako se utvrda Klek

tkanina i druge robe in Nabuchovica ad Lim super territorio comitis Pauli. R. Ćuk, "Kosače i Polmlje", str. 381; Međutim, do nove teritorijalne promjene došlo je iste godine u korist Srbije. Prema ugovoru od 18. srpnja 1405. navodi se jasna odrednica pripadnosti Banje ad partes Sclavoniae in loco vocato ecclesia S. Nicolay. M. Dinić, Srpske zemlje u srednjem veku, str. 123, bilj. 15; Sljedeće godine došlo je i do smjene vlasti i pomicanja granice Srbije prema Prijepolju. U jednom ugovoru, koji je registriran u Dubrovniku, krajem svibnja 1406.: vlah Herak Milošević, ponosnik, obvezao se dubrovačkom trgovcu Petru Lukareviću da će prevesti tkaninu i druge robe u mjesta Bukovicu i Prijepolje (ad partes Sclavonie videlicit in duobus locis primo in Buchoviza et in Priepogle). Iz ovoga izvora saznajemo da se Prijepolje 1406. godine nalazilo u sastavu Srbije, ali se nije dugo održalo u njezinu sastavu. R. Ćuk, "Kosače i Polmlje", str. 381; Za manastir Svetog Nikole u Banji pouzdano se zna da se u periodu od 1405. do 1415. nalazio u sastavu Despotovine. V. ŠAlipurović, nav. dj., str. 196, 203; S. Mišıć, Studije o srednjovekovnom Polimlju, str. 71. Ovi izvori jasno određuju da se tada dio Dabra, i to samo desna obala Lima, našla u granicama Srbije. U isto vrijeme, za crkvu Svetog Apostola Petra u župi Lim često je u ugovorima stajalo da karavane idu: ad partes Sclavonie ad ecclesiam S. Petri ultra flumen. M. Dinić, Srpske zemlje u srednjem veku, str. 123, bilj. 14.

35 Sinıša Mišıć, "Obnova Despotovine i njene granice: (1444-1459)", u: MoMČIlo Spremić (ur.), Pad Srpske despotovine 1459. godine, SANU, Beograd, 2011., str. 69.

36 Grad Brodar i planina Bujak spominju se u izvorima 1442. i 1449. godine da pripadaju vojvodi Ivanišu Pavloviću. M. Dinić, Zemlje hercega Svetoga Save, str. 182, 185-186; Dragiša Milosavljević, Srednjovekovni grad i manastir Dobrun, Dereta - Istorijski muzej Srbije - Zavičajni muzej, Beograd - Priboj, 2006., str. 30-31, 69-73; S. Mišı́́, Studije o srednjovekovnom Polimlju, str. 72.

37 Miloš Blagojević, Podrinje između srpskih srednjovekovnih država. Drina, Zavod za udžbenike i nastavna sredstva, Beograd - Srpsko Sarajevo, 2005., str. 57.

M. Dinić, Zemlje hercega Svetoga Save, str. 254. 
ubicira kao ostatci tvrđave u Rutoši, ${ }^{39}$ granica u Polimlju išla bi najvjerojatnije na utvrdu Oštrik u Zlatarskim Čelicama, gdje je planina Kitonja prirodna granica. Dolina Uvca ostaje Despotovini, ranije je pripadala knezu Lazaru, a dolina rječice Bistrice pripadala je Kosačama. Granica Kosača prema Mileševcu išla je obroncima Zlatara iznad sela Gornja Bistrica i zaseoka Zlatara, spuštajući se u izvorišni dio rijeke Mileševke. Obuhvaćajući župu Crnu Stenu i manastir Mileševo, granica se preko planine Jadovik i preko Stanjana spuštala prema Brodarevu. ${ }^{40}$

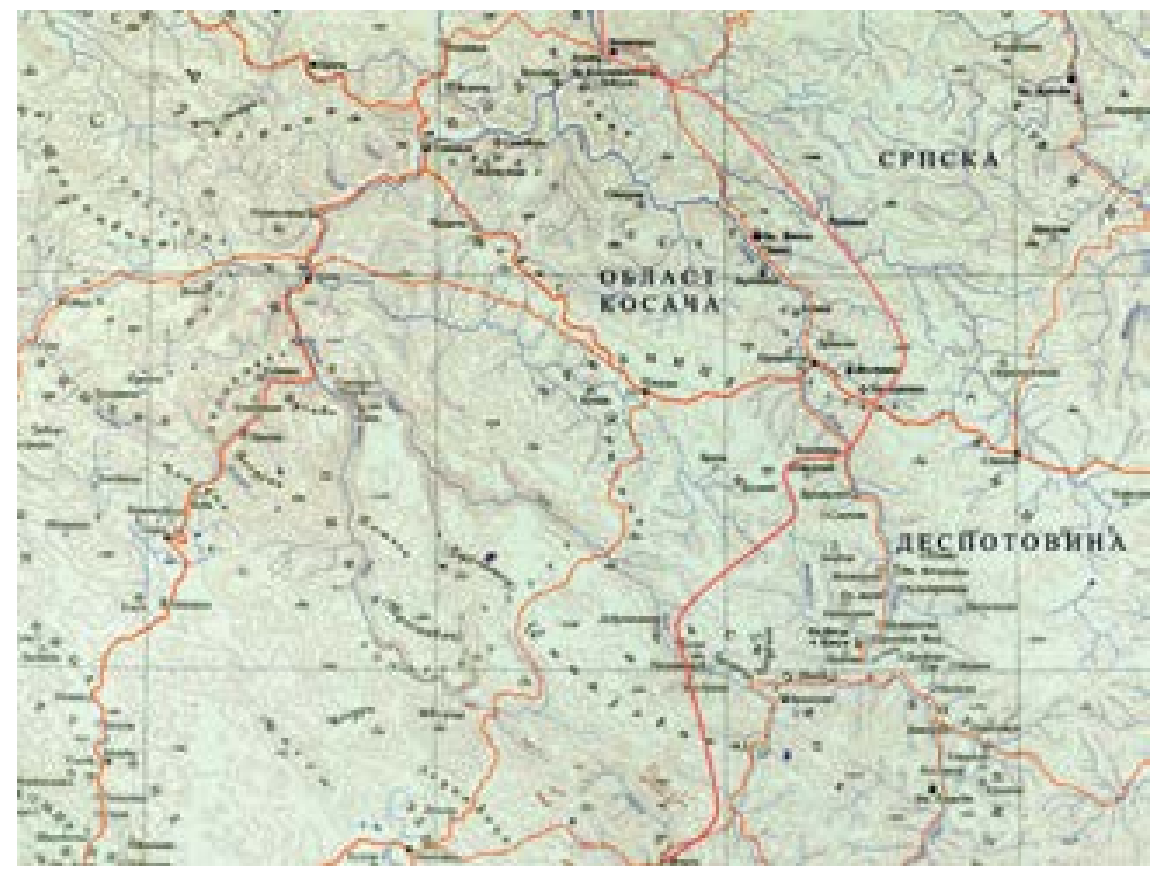

Karta: Granica između Despotovine i Kosača (rekonstrukcija urađena na podlozi povijesne karte u izdanju Istorijskoga instituta u Beogradu)

39 Utvrđenje je branilo dolinu Uvca i imalo je izvanrednu stratešku važnost. "Klek", u: Leksikon gradova i trgova srednjovekovnih srpskih zemalja - prema pisanim izvorima, str. 127.

40 S. Mišić, Studije o srednjovekovnom Polimlju, str. 73-74. 
Dubrovački izvori opisuju od 1422. do 1437. godine bosansko selo Brezu kao granično mjesto između Bosne i Srbije. U nekoliko ugovora Breza se navodi kao: usue ad locum que dicitur Bries ad confinia de Bosna et Sclauonia (19. lipnja 1425.); ad Bresam ad confinia Sclauonie (3. listopada 1436.); usque ad locum Brese confinis Sclauonie (15. travnja 1437.). Srednjovjekovna Breza odgovara današnjem selu Breza, između sela Mataruge i Kozice, u pljevaljskom kraju. Nedaleko od Breze kao prvo mjesto u Despotovini spominju se Komarani. Do njih se stizalo preko Breze ili, kako ponekad u arhivskim izvorima stoji, Komarani su se nalazili ispod Breze. U izvorima bilježi se kao selo ili mjesto. U jednom ugovoru, sklopljenom krajem rujna 1424. godine, zabilježeno je da 15 tovara tkanine treba prenijeti usque ad locum Comarani sub teritorio domini Georgii Volchouich. Ovaj podatak jasno saopćava da su Komarani pripadali despotu Đurđu Brankoviću. Prema ugovoru od 4. veljače 1434. da bi se odredio položaj Komarana navođena je Breza usque villam vocatam Comarani in Briesa districtum Sclauonie. Komarani su danas područje i istoimeno selo sjeverno od Brodareva. ${ }^{41}$ Dakle, granica se provlačila između Breze i Komarana, tako da je Maoče pripadalo hercegu. ${ }^{42}$ Granica je na Taru izbijala u oblasti Dobrilovine i obuhvaćala župu Brskovo, pa dalje išla preko planine Sinjajevine razvođem tako da su doline rijeka Bistrice, Štitarice i Plašnice pripadale despotu, a zapadni dio Sinjajevine pripadao je Kosačama. ${ }^{43}$ Ova granica održala se sve do pada Kosača pod osmansku vlast 1465. godine.

Raskid s bosanskim kraljem Tomašem 1448. godine dao je Stjepanu povoda da svoj položaj u bosanskoj državi formalno i naglasi uzimajući titulu hercega, u prvoj polovici listopada 1448. godine. Titula hercega u čitavoj Europi imala je veliku važnost i bila je odmah iza kraljevske. Stjepan Vukčić se sam proglasio hercegom i uzeo tu titulu u obliku: Stipan, Božjom milošću herceg humski i primorski $i$ veliki vojvoda Rusaga bosanskog, knez drinski i $k$ tomu. U jednoj povelji o isplati, 6. travnja 1449., Stjepan je u svojoj intitulaciji isticao da je Stipan, Božjom milošću herceg od svetoga Save i gospodar humski i

41 RužA Ćuk, "Breza i Komorani - srednjovekovna naselja u Polimlju", u: Istorijski časopis, XXXIV., Beograd, 1987., str. 61-73, gdje su navedeni svi ugovori o Brezi i Komaranima.

42 M. Dinić, Srpske zemlje u srednjem veku, str. 256.

43 Mıloš Luković, "Zajednička granica oblasti Kosača i oblasti Brankovića južno od reke Tare", u: Balkanika, XXXV., Beograd, 2005., str. 142. 
primorski i veliki vojvoda Rusaga bosanskog, knez drinski i $k$ tomu. U citiranoj tituli iskazana je samostalnost Stjepana Vukčića, a od ovoga datuma ustalila se jedinstvena titula herceg od svetog Save (duh Sancti Sabbae). Iz intitulacije vidimo da je on prvo gospodar humski $i$ primorski, a onda knez drinski. Ova titula stavljala je do znanja onovremenicima iz kojih se oblasti sastojao njegov posjed. U tituli je posebno istaknut kult svetoga Save, čime je naglašavao, preko manastira Mileševe, gdje su ležale "Savine mošti", vezu svojih zemalja sa starom srpskom državom i dinastijom Nemanjića. Titula herceg od svetog Save prikazivala je srpskoga svetitelja Savu kao zaštitnika Kosača i njegovih posjeda. Prema ovoj tituli hercegova zemlja bit će nazvana Hercegovina, a taj naziv sačuvat će se do danas. ${ }^{44}$

Dolina Lima bila je odredište do koje su dopirali karavani i ponosnici, odnosno tu se završavala prva etapa puta koji je išao iz Primorja prema unutrašnjosti Srbije. U Dubrovačkom arhivu sačuvan je velik broj ugovora o prijenosu robe iz Dubrovnika u Polimlje. Obavještenja o karavanskom prometu dobivamo najčešće iz dokumenata o dubrovačkim karavanima koji su na putu prema Dubrovniku doživjeli razne nezgode, napade, pljačke i sl. Najznačajnija karavanska stanica i trgovački centar u Polimlju bilo je Prijepolje, u župi Crna Stena. Opadanje važnosti Brskova doprinijelo je usponu Prijepolja, a težište karavanske trgovine pomjereno je u sedmom desetljeću XIV. stoljeća u dolinu Lima. Od toga vremena putevi kroz Polimlje postaju sve značajniji i prometniji. Povećava se broj karavana i trgovaca u oba smjera. Po dinamici karavanske stanice u Polimlju mogu se podijeliti u dvije grupe: prva obuhvaća one koje su bile aktivne krajem XIV. i u prva dva desetljeća XV. stoljeća: Bukovica, crkva svetoga Nikole u Banji, Ivanje, Ravno i crkva Mili. Drugoj skupini pripadaju: Breza i Drenova koje su dostigle vrhunac 20-ih i 30-ih godina XV. stoljeća. Iz dubrovačkih dokumenata ne možemo saznati koji su to bili razlozi za opadanje moći jednih te potom uzdizanja drugih trgovinskih centara u prvoj polovici 15. stoljeća. Poslije prvog pada Despotovine

44 S. Ćrrković, Herceg Stefan Vučić-Kosača i njegovo doba, str. 106-108; Sima Ćirković, "Mileševa i Bosna", u: Vojislav J. Đurić (ur.), Mileševa u istoriji srpskog naroda, Srpska akademija nauka i umetnosti, Beograd, 1987., str. 176-177; Rade MinaljČić, "Idejna podloga titule herceg", u: Radoslav BRATIĆ (prir.), Kosače - osnivači Hercegovine, Bileća - Gacko - Beograd, 2002., str. 308-335 (u radu su navedene sve intitulacije). 
1439. godine nastupilo je teško vrijeme, zamire karavanski promet između Dubrovnika i Polimlja. ${ }^{45}$

U lipnju 1455. godine osmanska vojska osvojila je Gornje Polimlje i jedan dio Srednjeg Polimlja koji su se nalazili pod vlašću Brankovića. Tijekom 1459. i 1460. Osmanlije su pustošile Bosnu, a ovo haranje nije zaobišlo oblast Kosača. Spalili su 18. studenoga 1459. manastir Mileševu i uznemirili čitavu oblast do dubrovačke granice. ${ }^{46}$ Herceg je uvidio da mu najveća opasanost sada prijeti od Osmanlija, pa je do kraja života ostao njihov neprijatelj. Tek krajem 1461. godine dolazi do pomirenja s kraljem Tomašem. Međutim, ponovo se buni njegov sin Vladislav, koji traži svoj dio teritorije i od Porte. Početkom 1463. godine spremao se veliki pohod Osmanlija, na čijem čelu se nalazio sultan Mehmed. ${ }^{47} \mathrm{U}$ ovom pohodu Osmanlije su zauzeli gotovo cijelu Bosnu. ${ }^{48}$ Hecegovu zemlju sultanov pohod nije zahvatio onom silinom kao Bosnu. Polimlje je stradalo početkom 1463. godine, u vrijeme kad su Osmanlije porazile hercega Stjepana na rijeci Breznici, blizu današnjih Pljevalja. U jesen 1463. herceg je dao trećinu svoga posjeda sinu Vladislavu. Stjepan je i dalje držao Donje Polimlje i Prijepolje s manastirom Mileševom. ${ }^{49}$

Početkom 1465. ponovo su zategnuti odnosi između oca i sina, ovaj sukob slabio je otpornu snagu hercega Stjepana. Osjetivši opasnost za svoje gradove u Polimlju i Gornjem Podrinju, on se sporazumio s ugarskim kraljem Matijom Korvinom da u gradove Mileševski, Soko, Tođevac i Samobor smjesti ugarske posade, koje će on izdržavati i zauzvrat mu dati posjede u Ugarskoj. Ovaj plan nije uspio jer je početkom ljeta 1465. godine sultanov namjesnik Isa-beg preduhitrio

Marijan Premović, "Trgovina i trgovački putevi u Srednjem i Donjem Polimlju u srednjem vijeku", u: Acta Histriae, 4, Koper, 2015., str. 693-713.

H. ŠABANović, Bosanski pašaluk: postanak i upravna podjela, str. 36; S. ĆIRKović, Istorija srednjovekovne bosanske države, Srpska književna zadruga, Beograd, 1964., str. 321-323.

47 S. Ćirković, Herceg Stefan Vučić-Kosača i njegovo doba, str. 238-250.

48 Emir O. Filipović, "Historiografija o padu Bosanskog Kraljevstva", u: ANTE BIRIN (ur.), Stjepan Tomašević (1461.-1463.) - slom srednjovjekovnoga Bosanskog Kraljevstva, Hrvatski institut za povijest - Katolički bogoslovni fakultet u Sarajevu, Zagreb - Sarajevo, 2013., str. 11-26.

49 H. ŠABANović, Bosanski pašaluk: postanak i upravna podjela, 38-39; S. ĆIRKović, Herceg Stefan Vučić-Kosača i njegovo doba, str. 252-261; MLADEN ANČıć, Na rubu Zapada. Tri stoljeća srednjovjekovne Bosne, Zagreb, 2001., str. 78-80, 111. 
hercega i ugarskoga kralja i započeo je s osvajanjem hercegove zemlje. Pri osvajanju Osmanlije nisu gledali jesu li to posjedi Stjepana ili Vladislava. Tom prilikom zauzeto je Prijepolje, Mileševac i Donje Polimlje. ${ }^{50}$ Osmanlije su zauzeli najveći dio hercegovih zemalja i njegovu vlast potisnuli na uski pojas oko Novoga i ušća Neretve. Iscrpljen od ratovanja herceg Stjepan je umro 22. svibnja $1466 .{ }^{51}$

Za vrijeme osmanskoga osvajanja velik je broj utvrda stradao. U sumarnom popisu sandžaka Bosna iz 1468./1469. godine na prostoru Polimlja upisana je samo jedna utvrda s posadom: Mileševac. Posadu Mileševca činilo je 19 posadnika, a dizdar tvrđave bio je Skender. Posadnici tvrđave bili su iz raznih krajeva: Kasim iz Anadola, Iljas iz Ćustendila i dr. ${ }^{52}$ Prema podatcima turskoga deftera sandžaka Hercegovina iz 1475./1477. godine posadu grada Mileševca sačinjavalo je 21 vojno lice. ${ }^{53}$ Ostale tvrđave na ovome prostoru Osmanlije napuštaju i uništavaju. Osmanskoj državi nije odgovarao veći broj tvrđava jer se njihova glavna osvajačka vojska povlačila, pa su u samo strateški značajnije tvrđave ostavljali posadu.

50 S. Ćirković, Herceg Stefan Vučić-Kosača i njegovo doba, 262-263; Veljan Atanasovski, Pad Hercegovine, Narodna knjiga - Istorijski institut, Beograd, 1979., str. 12-13; EmA Miljković-Bojanić, "Kraj vladavine Kosača i prve godine osmanske vlasti u Hercegovini", u: Radoslav Bratić (prir.), Kosače - osnivači Hercegovine, Bileća - Gacko - Beograd, 2002., str. 295; Dubravko Lovrenović, Na klizištu povijesti (sveta kruna ugarska i sveta kruna bosanska) 1387-1463, Synopsis, Zagreb - Sarajevo, 2006., str. 390-391; Milenko Krešić, "Depopulacija jugoistočne Hercegovine izazvana turskim osvajanjem", u: Povijesni prilozi, 39, Zagreb, 2010., str. 110.

51 S. Ćirković, Herceg Stefan Vučić-Kosača i njegovo doba, str. 263-267; Herceg Stjepan je 21. svibnja 1466. sastavio testament, dan prije smrti, diktiran mileševskom mitropolitu Davidu, uz prisustvo gosta Radina i komarnika Pribislava Vukotića. Vidjeti opširnije: Atanasije Jevtić, "O hercegu Stefanu Kosači (1435-1466) i njegovom testamentu", u: Gordana Tomović (ur.), Šćepan Polje i njegove svetinje kroz vjekove, Sveviđe, časopis eparhije Budimljansko-nikšićke - Manastir Zagrađe, Berane, 2010., str. 143-149.

52 A. S. Aličić, Sumarni popis sandžaka Bosna iz 1468/69. godine, str. 222-227.

53 H. ČAR-DRNDA, nav. dj., str. 112. 


\section{Herzog (Duke) Stjepan Vukcic Kosaca and Polimlje}

\section{Summary}

This paper will review the historical facts about Polimlje (Middle and Lower) at the time of Herzog Stjepan Vukcic Kosaca. The term Polimlje refers to the space of medieval parishes: Black Stone (the territory of the municipality of Prijepolje, Serbia) and Dabra (includes the municipality of Priboj in Serbia and Rudo in Bosnia and Herzegovina). The most important document about the settlements and fortresses of this area is the Charter of Herzog Stjepan Vukcic Kosaca which was twice released by Aragon and Naples King Alfonso V of Aragon (1444, 1454) and one by German "Roman" Emperor Friedrich III of Habsburg (1448). According to the plans of towns in these charters, the defense system of the Herzog Stjepan's area and all fortified towns with military crews which were protecting important roads and passes in the Herzog's authority can be seen. A special review is given to towns and fortresses: Milesevac, Kovin, Ostrik, Klek, Severin and Hrsovac.

Based on archival documents, diplomatic materials, and relevant historical literature we show the boundary between Kosaca and despotate. In October 1448, Sjepan takes the title of Herzog. In the charter dated 6 April 1449, especially prominent is the cult of Saint Sava. The Herzog emphasized through Mileseva monastery (with the relics of Saint Sava) his countries' relationship with the old Serbian state and dynasty of Nemanjic. The title was showing Saint Sava as protector of Kosaca and their possessions. After this title 'Herzog' the country was named Herzegovina, and that name has been preserved until today.

Prijepolje in Polimlje had a special role in the caravan traffic: it became the most important commercial and economic center. According to the dynamics of the station wagon ride in Polimlje there were two groups, the first included those that were active at the end of XIV and the first two decades of the XV century: Bukovica, the church of St. Nicola in Banja, Ivanje, Ravno and the church Mili. 
The second group included Breza and Drenova that have reached their peaks in the 20 -ies and 30 -ies of the XV century. In the early summer of 1465 the vicar of Sultan Isa Beg Ishakovic began with the conquest of Herzegovina. On this occasion Prijepolje, Milesevac and Lower Polimlje were occupied.

Keywords: Stjepan Vukcic Kosaca; Middle Ages; Polimlje; political situation; border; economy. 